\title{
Water-Energy-Food Nexus: Comparative Scenarios and Public Policy Perspectives from Some Latin American Countries Regarding Biogas from Agriculture and
} Livestock

Janaina Camile Pasqual ${ }^{1}$, Claudia Cecilia Lardizabal ${ }^{2}$, Gricelda Herrera ${ }^{3}$, Harry Alberto Bollmann ${ }^{4}$ and Estela de Oliveira Nunes ${ }^{5}$

1. International Center of Renewable Energies/Biogas and International Center of Hydroinformatics (Itaipu Binacional), Pontifical Catholic University of Paraná (PUCPR), CAPES Fellowship, Curitiba, Paraná 80030180, Brazil

2. Integrated Watershed Management, Biology Department, National Autonomous University of Honduras, San Pedro Sula, Cortes 21103, Honduras

3. Faculty of Social Sciences and Humanistic (FCSH), Research and Projects Applied on Earth Sciences Center (CIPAT), Escuela Superior Politécnica del Litoral (ESPOL), Guayaquil 09-01-5863, Ecuador

4. Urban Management Program, Pontifical Catholic University of Paraná (PUCPR), Curitiba, Paraná 80215-901, Brazil

5. Brazilian Corporation of Agricultural Research (EMBRAPA Soybean), Londrina, Paraná 86001-970, Brazil

\begin{abstract}
Latin American and the Caribbean countries have one of the world's largest sources of renewable energy. Nonetheless, it estimated that nearly three-quarters of their energy consumption relies on the use of fossil fuels, with most of the countries being net importers, ultimately imposing a marked economic and political dependence on those energy commodities. Therefore, the opportunity lies in a higher utilization of various renewable energy resources, which contribute to the country's energy security while promoting significant environmental benefits. This manuscript aimed to provide a comparative analysis of current energy scenarios of six Latin American countries (Mexico, Honduras, Nicaragua, Brazil, Chile and Ecuador) to evaluate their policies, programs and strategies implemented in the search for greater participation of renewable energy, with a special attention to biogas. Given the importance of the water-energy-food nexus that could foment the use of renewable energies under conditions of water scarcity, a qualitative data comparison was accomplished, considering biogas production potential, biogas projects and $\mathrm{CO}_{2}$ emissions.
\end{abstract}

Key words: Water and energy nexus, biogas, $\mathrm{CO}_{2}$ emissions, public policy.

\section{Introduction}

Most regions in the world are facing substantial increase in urbanization rates, and the management of their sustainability becomes an important focus of international efforts. According to the report of "world urbanization prospects" produced by the United Nations Department of Economic and Social Affairs [1], in the last century, the world's population living

Corresponding author: Janaina Camile Pasqual, assistant professor, research fields: water-energy-food nexus and biogas. in cities increased from $10 \%$ to $54 \%$, and this index is estimated to increase in the coming years, reaching $66 \%$ by 2050 . Accordingly, the urban population has risen from 750 million in 1950 to 3.9 billion in 2014 [1].

Although there is no consensus on what are the dimensions of sustainability, the process of urbanization should be connected to three main sustainable development aspects: economic, social and environmental. As noted by the Organization for Economic Co-operation and Development (OECD) 
[2], sustainable growth is necessary, because the challenges are increasing as the growth continues to erode the natural capital. If this is not taken into account, it will mean increased water shortages, depletion of natural resources, greater pollution, climate change and unrecoverable loss of biodiversity.

Therefore, an effective territorial management covering both urban and rural areas and looking for solutions to many global challenges are necessary. This study will explore the sustainable development under the inseparable three axes that support the existence and survival of human life: water, energy and food. Water is an input for the production of agricultural commodities, and it is also used along the supply chain. Energy is required to produce and distribute food and water, as to pump water from underground or surface water sources, to move tractors and irrigation machines and to process and transport commodities. And food is necessary to keep us alive, mainly due to the population growth estimates. These three axes are under constant pressure due to their status as "life support priorities", but providing food and energy as well as ensuring water for all are challenges of the same magnitude and complexity that are not totally overtaken.

Food and Agriculture Organization of the United Nations (FAO) [3] states that the projected increase of food production is $50 \%$ by 2050 , which will require $45 \%$ more energy and $30 \%$ more water. This could be achieved by increasing the efficiency in energy production and use of renewable sources.

At this juncture, biogas stands out as systemic energy being generated by the proper treatment of plant, animal, human and industrial waste, turning environmental liabilities into economic assets through two different ways: direct electrical power generation-thermal or vehicular/biomethane, and indirect reduction of greenhouse gas emissions and thus mitigating global warming.

In addition, biogas is the source that most likely resembles hydraulic energy, since it can be stored and dispatched continuously. Unlike solar and wind sources characterized by its flashing inputs in the networks, biogas can still be purified and converted into biomethane, which can be replaced with fossil fuels as a transportation fuel.

The present research aimed to study the benefits of biogas and biomethane for sustainable regional development based on the water-energy-food nexus, and analyze existing public policies for biogas in six Latin American countries: Brazil, Chile, Ecuador, Honduras, Mexico and Nicaragua. In addition, it presents some best practices and pilot projects on this issue.

\section{Biogas Scenario in Some Latin American Countries}

According to the United Nations [4], the most urbanized regions of the world are in Northern America (82\%), Latin America and the Caribbean (80\%) and Europe (73\%), and this scenario will continue to increase (Fig. 1). Chile is the most urbanized (89\%), followed by Brazil (85\%), México (79\%), Ecuador (64\%), Nicaragua (58\%) and Honduras (54\%).

As the world continues to urbanize, sustainable development challenges will be increasingly concentrated in cities, where it's necessary to implement policies to ensure that the improvement of urban growth are shared equitably and sustainably.

The Rio+20 Conference "The future we want" held in 2012 [5], recognized that cities can lead the way towards economically, socially and environmentally sustainable societies, but it's very important of a holistic approach to urban and rural planning. Sustainable urbanization requires, among others, that cities expand the necessary infrastructure for water and energy, preserve the natural assets within the city and surrounding areas, and manage the increasing amount of wastes. Leimgruber [6] affirms that "waste has developed into a major predicament because of the many problems associated with it: area needed for 


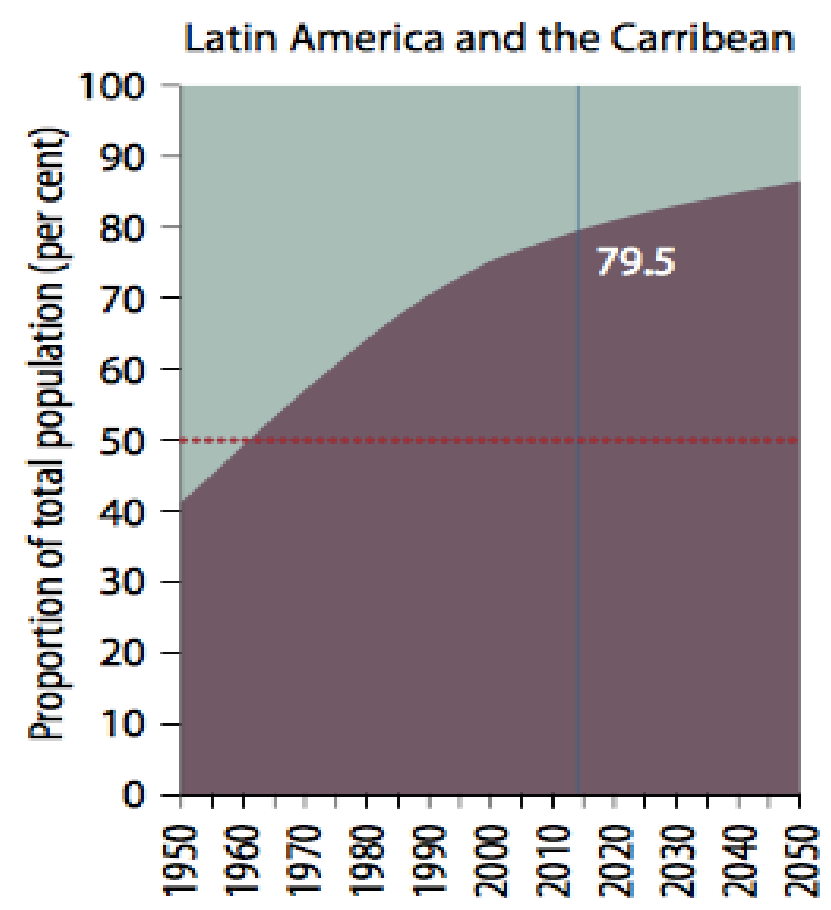

Fig. 1 Latin America and the Caribbean urban and rural population from 1950 to 2050.

Source: United Nations, 2014.

landfills, risks to groundwater, air pollution from incinerators and difficulty of finding final dumps for cinders without harm to the environment and human health".

This scenario is appropriate for biogas projects, as it is possible to convert organic materials arising from wastes (biomass) into electrical, thermal and automotive energy, consequently treating wastewater and avoiding water pollution.

According to Fuchs et al. [7], "the gases are primarily methane and $\mathrm{CO}_{2}$. Fermentation residues, which also remain, are used as liquid fertilizer in crop production. Methane can be supplied into the natural gas pipeline after special treatment, or in most cases, it is burned in a gas-combustion engine generating electricity and thermal energy”.

\subsection{North America-México}

The Mexican economy is highly dependent on petroleum production. However, the extraction of petroleum is diminishing, and nowadays there are great difficulties to keep constant supply, which is why strategies for diversifying the ways energy are being planned. The share of renewable energy represents only a low percentage, and observing the current development of clean energy production, a slightly significant short-term growth projection is expected [8]. However, a strategy for a cleaner energy matrix has come in effect through different policies and programs that incentivize low energy consumption by the population, disposable of high-energy consumption equipment, energy saver light bulbs, among others.

The agricultural, fishery and forestry sector in Mexico represents $3.6 \%$ of national GDP, and livestock activities account for around $23 \%$ of the sectorial production [9]. The animal wastes from livestock farms represent a significant negative impact on the local environment through pollution of water bodies and global GHG emissions due to the current poor waste management. A study produced by the International Renewable Resources Institute (IRRI) of Mexico [10] affirms that the agriculture sector generates over 46 million tons of carbon dioxide 
equivalent ( $\left.\mathrm{Mt} \mathrm{CO}_{2} \mathrm{eq}\right)$ per year, with methane in the livestock sub-sector contributing around $80 \%$ of the overall agriculture sector methane emission (over 38 million $\left.\mathrm{Mt} \mathrm{CO}_{2} \mathrm{eq}\right)$. In another hand, it creates an opportunity to manage and treat the waste by anaerobic digestion, and hence, this process captures the methane-rich biogas generated as a by-product.

The potential of biogas in livestock activity is about 9,344,459 million $\mathrm{m}^{3} /$ year $\left(\mathrm{Mm}^{3} /\right.$ year) or 13,362 gigawatt/year ( $\mathrm{GW} / \mathrm{year})$, less than $1 \%$ of the total demand, but even so, it's a meaningful amount of clean energy [10].

\subsection{Central America}

\subsubsection{Honduras}

The energy matrix has experienced constant changes in the past decades. In 1980, for example, the Francisco Morazán "El Cajon” Dam was built and provided $100 \%$ of residential use and $69 \%$ of total energy required by the country. However, due to an $8 \%$ annual energy demand increase, a prolonged drought and technical construction flaws, the energy matrix changed [11]. Currently, Honduras is highly dependent on hydrocarbons for energy generation. In 2012, Honduras presented the biggest increase in hydrocarbons consumption (3.2\%) in Central America, followed by Panama (2.2\%) and Guatemala (0.2\%) [12]. Besides, Honduras is a net importer of petroleum fuels, mainly from the US (48.8\%), Ecuador (13.1\%) and Venezuela (13.1\%) [13]. Central America has not confirmed petroleum reserves, which makes it highly dependent on foreign energy sources.

Honduras relies heavily on fossil fuels, with $62 \%$ of the nation's energy production coming from non-renewable sources, primarily, thermo-based power systems, which are vulnerable to high and volatile international oil prices. The remaining 38\% comes from renewable energy, $34 \%$ of which is hydropower [11]. A strategy for the improvement of the energy matrix has been adopted by public policies that promote fiscal, financial, market and legal incentives for renewable energy production. This is a positive step forward, as it is important to mention that Honduras is the biggest generator of GHG in Central America due to its electrical energy sub-sector and its high dependence of thermal energy [12].

A study in order to determine the potential of biogas production was done with the support of United Nations Development Programme (UNDP). In general, the data from this study indicate a national biogas potential derived from productive activities of 430 meganewton per cubic metre $\left(\mathrm{MN} / \mathrm{m}^{3}\right)$ biogas at $60 \% \mathrm{CH}_{4} /$ year. This represents a total of to 180 megawatt electric/year (MWe/year) of electric potential [14]. Considering that Honduras consumes about 1,200 MWe/year of electric energy, this amount represents 15\% [15].

After Mexico, Honduras is the 2nd country with clean development mechanism projects and is the 7th in Latin America. Most of the country projects correspond to the hydroelectric category, followed by cogeneration with biomass and methane and biogas recovery.

\subsubsection{Nicaragua}

The energy matrix consists predominantly of fossil fuels. However, the share of renewable energy has grown meaningfully in recent years. According to the Nicaraguan Energy Institute [16], in 2011, 65\% of its energy derived from oil, $30 \%$ from renewable resources $^{1}$ and $5 \%$ from large hydropower plants. The Nicaraguan pattern energy historically responds to a structural problem with high dependence on imported oil-over $70 \%$ of thermoelectric generation with fuel oil and diesel in 2007. This factor has limited the economic development due to the growing trend in oil's international prices [11].

Nicaragua has more than 5,000 MW/year of potential capacity to generate renewable energy, of which 2,500 MW/year correspond to hydroelectric power, 1,500 MW/year to geothermal energy, 800

\footnotetext{
${ }^{1}$ Composed by $5 \%$ small hydropower (SHP), 6\% wind, $8 \%$ geothermic and $11 \%$ biomass and wastes.
} 
MW/year to wind power and $200 \mathrm{MW} /$ year to biomass. The Indicative Plan of Ministry of Energy and Mines [17] states that for 2017 only 6\% of generated electric energy will come from thermoelectric plants, contrasting with $65.3 \%$ in 2010. It will increase generation from 3,321 GWh for 2010 to $4,823 \mathrm{GWh}$ in 2017, with great participation of hydropower and geothermic energy, $41 \%$ and $35 \%$ of total generation, respectively.

Even though renewable energy is a step forward, there is a long way ahead before it can be seen also as "sustainable" energy. The country needs investments to change fuel wood consumption patterns and associated deforestation, as well as a stronger regulatory capacity to ensure that big investments for the construction and operation of renewable electric energy also meet the required environmental standards.

According to World Bank [18], which compares emissions of GHG in Latin America, Nicaragua is the Mesoamerican country reporting fewer emissions per capita and ranking among the four countries of Latin America with lower emissions. Nevertheless, the change in the electric matrix will mean a significant emission reduction.

Nicaragua is an agrarian economy based on export of agricultural products, such as bananas, coffee, sugar cane, corn and sesame. Livestock is an activity highly developed in Nicaragua, and beef ranks the second among the main products of export, after coffee, which represents a potential biogas generation [19].

The use of biogas as an alternative energy source was introduced in Nicaragua in the1980s. In 1984, the government with funding from the Latin American energy organization started the construction of bio-digesters in coffee processing plants, in the department of Matagalpa. At this time, they also implemented the biogas program for coffee effluent, and the national biogas program and use of agricultural by-products.

From 1992 to 2006, 500 bio-digesters were built primarily domestic and in small coffee and cattle farms. In 2007, the theme was taken up by the present government, through the "Zero Hunger" food production program, 800 bio-digesters were installed as part of the aid package to poor families, in order to replace wood for biogas (cooking) and reduce wood consumption [19]. According to the Nicaraguan Institute of Statistical Studies [20], the results of the bio-digesters implementation were satisfactory, mainly regarding environmental improvement by reducing the consumption of wood, as well as soil improvement. Most families continue using the biogas for cooking and improving environmental sanitation.

The country has one of the lowest levels of access to energy in Latin America and the Caribbean, where $26 \%$ of the population without access to electricity [21]. In this context, the biogas can represent a sort of renewable energy that has great potential to improve access to modern energy in urban and rural areas.

\subsection{South America}

\subsubsection{Brazil}

This country has one of the most privileged energy matrices of the world, with almost half of the energy (41\%) arising from renewable sources, while the world average is $13 \%$, and in developed countries is only $8.1 \%$ [22]. The main renewable sources in the energy matrix are: sugar cane biomass (16.1\%), hydropower (12.5\%), firewood and charcoal (8.3\%), lixivium and others (4.2\%).

Regarding electrical power generation, the Brazilian scenario is even more sustainable, with $79.3 \%$ of renewable sources. According to the National Energy Report [23], the renewable electricity production expanded by $1.7 \%$ points in 2013, due to biomass from sugarcane and increased wind generation. Brazilian power model remains heavily dependent on hydropower, which represents large dependence on current and future sector in relation to water use available in the country.

The electricity generation in Brazil increased 3.2\% 
in 2013 over 2012, reaching 570,000 GWh. The main generators are the public utilities, with $85.5 \%$ of total generation, which uses hydropower as the main source.

The sectors that consume the most overall energy are: industry (33.9\%), followed by transportation (32\%), energy sector (10\%), residential use (9.1\%), non-energy use (6.3\%), commercial and public services (4.6\%) and agriculture (4.1\%). Industrial production, freight transport and mobility of people and families represent $66 \%$ of energy consumption in the country [23].

As the largest tropical country in the world, Brazil receives, throughout the year, intense solar radiation, which is the basis for the production of biogas. Allied to this factor, the country has a very representative agribusiness, specially composed by grain production activities and animal protein, which greatly favor the country to develop clean and renewable energy technologies, taking advantage of the waste generated by these activities and diversifying its energy matrix.

Brazil has a great potential of agricultural residues, including livestock wastes which is the focus of this study. Estimates suggest that biogas and biomethane potential in Brazil is about 15 billion $\mathrm{m}^{3} /$ year, considering agricultural/industrial sectors, treatment of animal waste and effluents, and sugarcane production [24].

In 2013, total anthropogenic emissions associated with the Brazilian energy matrix have reached 459 million $\mathrm{Mt} \mathrm{CO}_{2} \mathrm{eq}$, most (215.3 Mt $\mathrm{CO}_{2} \mathrm{eq}$ ) of which generated in the transportation sector. To produce and consume energy, every Brazilian emits on average 2.2 tons of $\mathrm{CO}_{2}$ per habitant, which is three times less than Europe (7.1 tons $\mathrm{CO}_{2}$ /habitant), eight times less than the United States (16.9 tons $\mathrm{CO}_{2}$ /habitant) and less than half of China (5.1 tons $\mathrm{CO}_{2}$ /habitant) [23].

\subsubsection{Ecuador}

The energy matrix is composed predominantly by fossil fuels, which represents $94 \%$ of total primary energy production. Hydropower represents 4\%, sugarcane biomass for electricity generation represents $1 \%$ and wood biomass represents less than $1 \%$. The oil sector represents $10 \%$ of economic activity in Ecuador, representing more than $50 \%$ of income for total exports of the country [25].

The country has a tropical climate, representing favorable conditions for biogas generation. The agriculture and livestock sectors have great potential for the various renewable energy technologies [26]. According to the Ecuador's National Institute of Statistics and Census [27], the area of agricultural labor in 2013 was 7.32 million ha, such as cultivated pastures 44.07\%, natural pastures $22.17 \%$, permanent crops $20.06 \%$ and transitory crops and fallow land $13.70 \%$.

The agricultural total production in the Ecuador of the year 2013 is 18,374,608 metric tons, classified in permanent crops (sugar cane, oil palm and banana) and transitory crops (rice, hard corn and potatoes). In the sector livestock, it predominates over poultry production with 51,750 million national heads, followed by the cattle with a total of 5.1 million national heads, followed by the swine with 1.2 million heads [27].

The biogas energy potential in the livestock sector is about 1,854 GW [28].

Regarding $\mathrm{CO}_{2}$ emission per capita, in 2012 Ecuador was about 2.3 metric tons, next to Brazil (2.2 metric tons), and below Chile (4.6 metric tons) and Mexico (3.9 metric tons) [29].

\subsubsection{Chile}

The energy matrix of Chile is composed by $90 \%$ petroleum, $4 \%$ natural gas, 3.3\% hydropower, $1.4 \%$ sugarcane and $1.3 \%$ firewood [30].

Chile has a strong external dependence associated with the import of energy used, which in 2011 was around $78 \%$ of the country's total energy matrix [30]. Imported energy is consumed in the form of coal, petroleum and gas. This situation exposes the country to variations of international fuel prices raising the final costs of the energy, which are transferred to consumers. The Chilean energy matrix is primarily 
based on thermoelectric and hydroelectric energy.

The Chilean electric matrix comprises two electrical systems of great extent: the Central Interconnected System (SIC) which corresponds to $73.6 \%$ of total installed capacity and the Large North Interconnected System (SING) which represents 25.6\%, and four minor electrical systems: Aysen Electrical System, Magallanes Electrical System, the Lakes Electrical System and the Easter Island Electrical System. These electric grids are configured by installations of generation stations, electric substations, transmission lines and distribution lines that interconnect all of the projects described above. Currently, the electric energy generated by renewable sources reaches $5.06 \%$ of the installed capacity of the national energy matrix, considering for these calculations, the biomass energy, wind energy, solar energy and hydroelectric energy less than $20 \mathrm{MW}$ [30].

The SIC electric matrix is composed by $45 \%$ hydropower, $22 \%$ diesel, 15\% coal, 13\% liquefied natural gas, $3 \%$ biogas and $2 \%$ biogas, while the SING electric matrix is composed by $52 \%$ coal, $28 \%$ diesel, 19\% liquefied natural gas (LNG) and 1\% biomass, with no hydropower [31].

The $\mathrm{CO}_{2}$ emissions in Chile have increased during the years. In 1990, the $\mathrm{CO}_{2}$ emissions per capita were 2.6 metric tons, and in 2010 were 4.2 metric tons with an increase of $60 \%$ [18].

The Planning Guide for Biogas Projects in Chile [31] concluded that the conversion of biomass to methane as a source of non-conventional renewable energy is feasible in the country. The estimate potential is about $400 \mathrm{MW}$ of installable capacity for electricity generation, which means about $3.5 \%$ of current capacity. The biogas potential in Chile, considering agriculture and livestock is about 13,675 MW/year [32].

\section{Methodology}

This study uses a qualitative analysis to identify aspects that should shape the development of biogas of six Latin American countries (Fig. 2).

First of all, the energy matrix of each country was analyzed, considering the share of fossil fuels and renewable sources of energy. After, the focus was on biogas production potential and $\mathrm{CO}_{2}$ emissions, taking into account the agricultural and livestock sectors in each country. For this purpose, the authors used a state-of-the-art literature review in academic and institutional reports, books, government reports and official national documents.

After this initial analysis, the study considered the public policies and regulatory framework regarding biogas production adopted in each country. With the data obtained, it was possible to make a comparative evaluation of each country and know some pilot projects that are been developed in this area, which could serve as a benchmark to other countries.

Lastly, the authors synthesized the findings derived from individual countries and presented a preliminary prognosis for Latin America.

\section{Results and Discussion}

In order to evaluate the biogas potential from agriculture and livestock, Table 1 compiles general basic characteristics of the countries in this study.

It is possible to verify that, even considering the size of each country, all of them have representative agricultural and animal production. Brazil and Mexico are the countries that generate more quantity of livestock biogas (70,830 GW and 13,363 GW, respectively), followed by Ecuador (1,855 GW), Chile (1,676 GW), Nicaragua (1,192 GW), and Honduras (909 GW).

Table 2 presents the $\mathrm{CO}_{2}$ emissions and access to electricity in these countries. It indicates that Chile is the country that has the most per capita $\mathrm{CO}_{2}$ emissions, followed by Mexico and Ecuador. Regarding the total $\mathrm{CO}_{2}$ emissions, Mexico is the country that has more emissions, followed by Brazil and Chile.

The access to electricity in these countries is above the world average (82\%), except for Nicaragua. Chile 


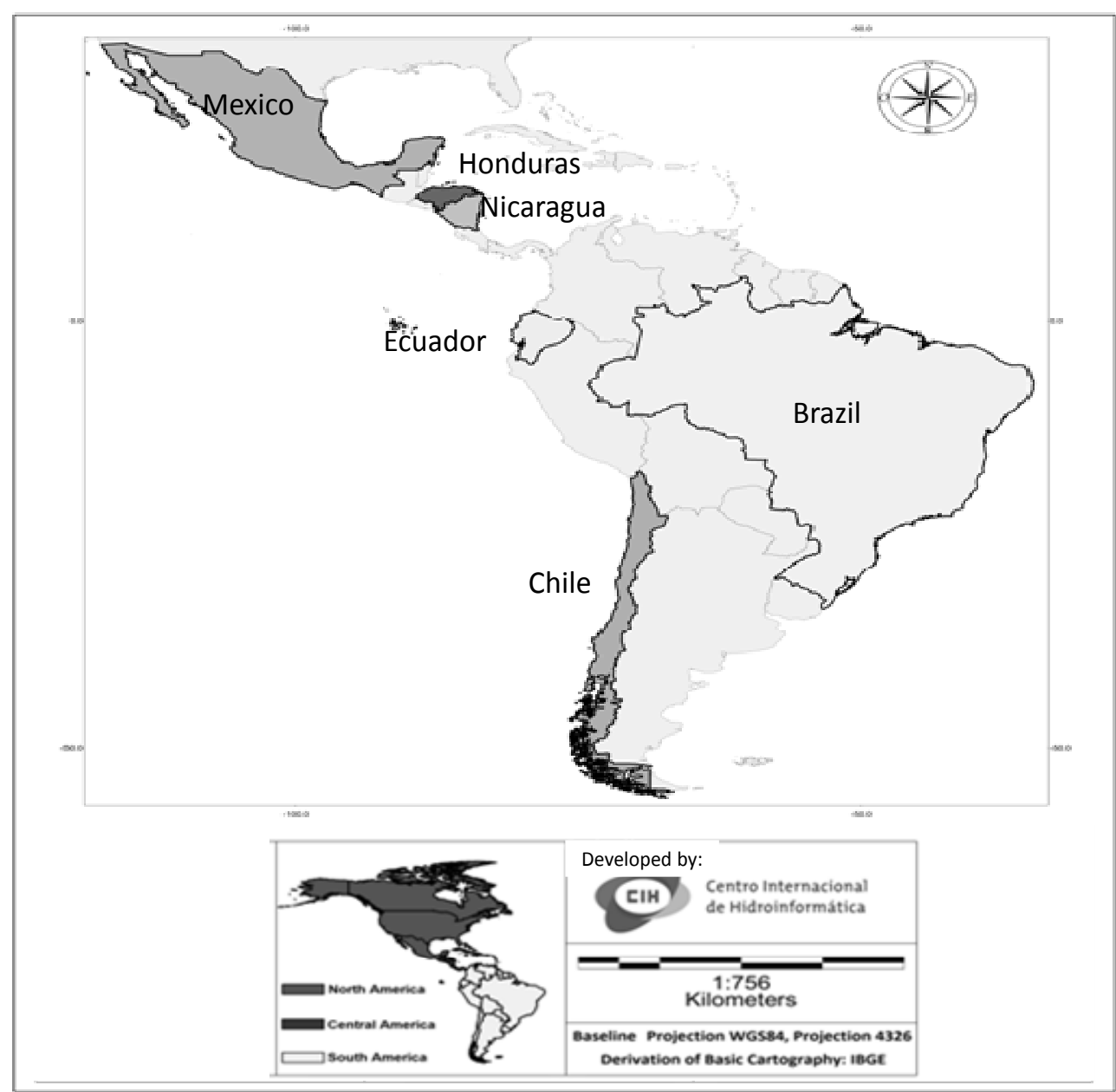

Fig. 2 Countries involved in the study.

Source: International Hydroinformatics Center, Brazil, 2014.

is the most developed in this scenario (99.6\%), followed by Brazil (99.5\%) and Mexico (99.1\%). This indicator is important to present the opportunities, which some countries has to stimulate biogas energy that can be produced and consumed locally.

Analyzing the Tables 1 and 2, it's possible to state that Honduras and Nicaragua have the lowest potential for biogas production, but they are countries where this energy would have a greater social effect, due to the low access to electricity. Mexico has great potential for bio-digestion power generation, but has already a high $\mathrm{CO}_{2}$ production. At that point, Brazil, which also has great potential for bio-digestion power generation, has a lower production of $\mathrm{CO}_{2}$, or has more opportunity for energy production by bio-digestion.

In the next section, public policies of the studied countries will be analyzed, focusing on the evolution of the regulatory framework in the last decades.

\subsection{Biogas Projects and Public Policies of the Involved Countries}

\subsubsection{North America-Mexico}

Although anaerobic digestion has been in use in Mexico since the 1970s, in that decade some mistrust was created through the poor delivery of several bio-digester projects intended to generate certified emission reductions (CERs or “carbon credits”). During 2006 and 2007, a lack of administrative and financial capacity in several CER trading companies 
Table 1 General information in selected Latin America countries in 2014.

\begin{tabular}{|c|c|c|c|c|c|}
\hline Country & $\begin{array}{l}\text { Territory } \\
\left(\mathrm{km}^{2}\right)\end{array}$ & Population & $\begin{array}{l}\text { Agricultural } \\
\text { production (ton) }\end{array}$ & Numbers of animals & Biogas energy potential (MW/year) \\
\hline \multirow{4}{*}{ Brazil } & \multirow{4}{*}{$8,515,767$} & \multirow{4}{*}{$204,621,608$} & \multirow{4}{*}{$192,858,762$} & \multirow{4}{*}{$\begin{array}{l}\text { C: } 211,764,292 \\
\text { S: } 36,743,593 \\
\text { P: } 1,032,038,992 \\
\text { Total: } 1,280,546,877\end{array}$} & $63,002,312$ \\
\hline & & & & & $3,787,718$ \\
\hline & & & & & $4,040,046$ \\
\hline & & & & & $70,830,076$ \\
\hline \multirow{4}{*}{ Chile } & \multirow{4}{*}{756,950} & \multirow{4}{*}{$17,772,871$} & \multirow{4}{*}{$9,995,8971$} & \multirow{4}{*}{$\begin{array}{l}\text { C: } 3,305,365 \\
\text { S: 5,499,243 } \\
\text { P: } 32,000,000 \\
\text { Total: 40,804,608 }\end{array}$} & 983,384 \\
\hline & & & & & 566,890 \\
\hline & & & & & 125,268 \\
\hline & & & & & $1,675,542$ \\
\hline \multirow{4}{*}{ Ecuador } & \multirow{4}{*}{256,370} & \multirow{4}{*}{$16,306,392$} & \multirow{4}{*}{$18,374,608$} & \multirow{4}{*}{$\begin{array}{l}\text { C: } 5,134,122 \\
\text { S: } 1,219,000 \\
\text { P: } 51,570,000 \\
\text { Total: } 57,923,122\end{array}$} & $1,527,460$ \\
\hline & & & & & 125,661 \\
\hline & & & & & 201,877 \\
\hline & & & & & $1,854,998$ \\
\hline \multirow{4}{*}{ Honduras } & \multirow{4}{*}{112,090} & \multirow{4}{*}{$8,260,749$} & \multirow{4}{*}{$22,710,6713$} & \multirow{4}{*}{$\begin{array}{l}\text { C. } 2,774,000 \\
\text { S: } 165,000 \\
\text { P: } 17,000,000 \\
\text { Total: } 19,939,000\end{array}$} & 825,297 \\
\hline & & & & & 17,009 \\
\hline & & & & & 66,549 \\
\hline & & & & & 908,855 \\
\hline \multirow{4}{*}{ Mexico } & \multirow{4}{*}{$1,972,550$} & \multirow{4}{*}{$125,424,677$} & \multirow{4}{*}{$238,559,104$} & C: $32,402,461$ & $9,640,105$ \\
\hline & & & & S: $16,201,625$ & $1,670,147$ \\
\hline & & & & P: 524,271,158 & $2,052,325$ \\
\hline & & & & Total: 572,875,244 & $13,362,576$ \\
\hline \multirow{4}{*}{ Nicaragua } & \multirow{4}{*}{129,494} & \multirow{4}{*}{$6,169,269$} & \multirow{4}{*}{$2,994,014$} & & $1,112,693$ \\
\hline & & & & S: 418,529 & 43,144 \\
\hline & & & & P: 9,400,000 & 36,797 \\
\hline & & & & Total: $13,558,529$ & $1,192,635$ \\
\hline
\end{tabular}

Adapted of Instituto Brasileiro de Geografia e Estatística (IBGE) 2015, Oficina de Estudios y Políticas Agrarias (ODEPA) 2015, Instituto Nacional de Estadistica (INE) 2014, Centro de Información Científica y Humanística (CICH) 2015 and Servicio de Información Agroalimentaria y Pesquera (SIAP) 2015.

The biogas energy potential calculation methodology considered the extracted indexes in Kunz and Oliveira [33].

C: cattle, S: swine and P: poultry.

Table $2 \mathrm{CO}_{2}$ emissions and access to electricity in selected Latin American countries in 2014.

\begin{tabular}{llll}
\hline \multirow{2}{*}{ Countries } & \multicolumn{2}{c}{$\mathrm{CO}_{2}$ emissions } & Access to electricity \\
\cline { 2 - 4 } & (ton/capita) & $\left(\times 10^{3}\right.$ ton $)$ & $(\%)$ \\
\hline Chile & 4.6 & 79,409 & 99.6 \\
Mexico & 3.9 & 466,549 & 99.1 \\
Ecuador & 2.3 & 35,728 & 97.2 \\
Brazil & 2.2 & 439,413 & 99.5 \\
Honduras & 1.1 & 8,412 & 82.2 \\
Nicaragua & 0.8 & 4,899 & 77.9 \\
\hline
\end{tabular}

Source: The World Bank, 2015.

who were implementing agricultural aerobic digestion projects, meant that these systems were poorly installed.

In 2009, the Mexican Ministry of Agriculture, Livestock, Rural Development, Fisheries and Food
(SAGARPA) accompanied a national inventory of anaerobic digestion systems and documented a total of 721 systems installed throughout 11 states of Mexico. This number only represents the large systems installed in pig and dairy farms and does not include 
Table 3 Mexican regulatory framework.

\begin{tabular}{|c|c|c|}
\hline $\begin{array}{l}\text { Law or regulatory standard } \\
\text { (NORMA) }\end{array}$ & $\begin{array}{l}\text { Applicability to anaerobic digestion } \\
\text { projects }\end{array}$ & Description of NORMA \\
\hline NOM-005-STPS-1998 & Biogas storage & $\begin{array}{l}\text { Regulations on health and safety conditions in the workplace; } \\
\text { Handing, transportation and storage of hazardous chemicals. } \\
\text { Regulations on health and safety signing; }\end{array}$ \\
\hline NOM-026-STPS-2008 & Biogas transportation lines & $\begin{array}{l}\text { Pipes carrying biogas should be painted yellow, marked, } \\
\text { identified and subject to maintenance. It should be indicated } \\
\text { that the pipes transport flammable fluids. }\end{array}$ \\
\hline NOM-003-SECRE-2002 & Biogas transportation lines & $\begin{array}{l}\text { Distribution of natural gas and liquefied petroleum gas via } \\
\text { pipelines. }\end{array}$ \\
\hline NOM-002-STPS-2000 & Risk of fire from biogas & $\begin{array}{l}\text { Determine the degree of risk of fire, including areas where } \\
\text { fire extinguishers should be installed for the bio-digester; } \\
\text { Fit fire equipment type A and in the case of electrical areas, } \\
\text { install equipment type C according to the NORMA. }\end{array}$ \\
\hline NOM-001-SEDE-2005 & $\begin{array}{l}\text { Use of biogas generators for electricity } \\
\text { generation }\end{array}$ & Utilization of electrical installations. \\
\hline NOM-029-STPS-2005 & $\begin{array}{l}\text { Use of biogas generators for electricity } \\
\text { generation }\end{array}$ & Maintenance of electrical installations in the workplace. \\
\hline NOM-017-STPS-2008 & System operating staff & Equipment for Personal Protection in the workplace. \\
\hline
\end{tabular}

Source: International Renewable Resources Institute (IRRI), 2014 [10].

systems installed in other industries and backyard farms. From 2008 to 2010, a total of 221 anaerobic digesters were implemented in Mexico with Fideicomiso de Riesgo Compartido (FIRCO) from the Department of Agriculture, that is a parastatal entity created to promote agribusiness, rural development and acting as micro-technical staff in programs of agricultural and fisheries sector [34].

Within the context of decentralized energy, several changes to Mexican policy have helped bio-digester owners to generate and sell electricity produced from biogas. Prior to the utilization of renewable energies and financing for the energy transition law in 2008, it was not legal for individuals or organizations other than the Federal Electricity Commission to generate or sell electricity.

The main regulatory considerations for agricultural livestock biogas projects in Mexico are summarized in Table 3.

It is also important to highlight other legal evolutions:

(1) In 2010, technical standards for the design and construction of bio-digesters in Mexico were created;

(2) In 2012, the law authorized that the Energy Regulatory Commission generated the general rules for interconnection to the national electricity grid by electricity generators or permittees with sources of renewable energy or efficient co-generation. These general rules were published in May 2012 and allow independent electricity generators to connect to the national electricity grid through an interconnection contract with the Federal Electricity Commission, which institutes conditions for billing of electricity demanded by the facilities associated with the project as well;

(3) As the compensation scheme the project is entitled, when it generates more electricity than required.

There are three different categories of contract for interconnection:

(1) Small scale-applies to systems for residential use up to $10 \mathrm{~kW}$ and general use up to $30 \mathrm{~kW}$;

(2) Medium scale-applies to systems up to 500 $\mathrm{kW}$. It is possible to use the electricity generated under a portage self-sufficiency scheme;

(3) Generation centers-applies for large scale of more than $500 \mathrm{~kW}$. It is possible to sell electricity back to Federal Electricity Commission (surplus sale).

The IRRI founded in Mexico in 2003 created the biogas programme, which aims to promote the health, economic and environmental benefits that digester provision to small farmers, their families and their communities through improved waste management, 
power generation and the generation of organic fertilizer; protect forests, watersheds and groundwater; promote organic agriculture; improve health conditions in the housing; reduce the emission of GHGs and provide low cost solutions to reduce the risks of climate change [10].

One of the results is the WISIONS project $^{2}$ "removing barriers to greenhouse gas mitigation in medium scale livestock agricultural activities in Mexico, 2014-2015”. This project aims to promote the productive use of biogas in medium producers through the adaptation of gasoline engines to generate electricity and mechanical energy. There are currently a small number of medium-scale producers using biogas in their farms for productive activities group, this is due to the limited supply of motor generators for biogas small spelled in the Latin American market [32]. Therefore, IRRI Biobolsa and a group of engineers plan to develop and install a total of 20 engines-16 in small farms and 4 in medium-scale farms in central Mexico. The engines will be used to jump-start milking vacuum pumps, water pumps and sludge, small grain mills, as well as to generate electricity within the facility [10].

\subsubsection{Central America}

\subsubsection{Honduras}

Honduras is the second country in central America (after Mexico) with clean development mechanism projects; most of the projects correspond to the hydroelectric type, and the rest consist of cogeneration with biomass and recovery of methane and biogas. There are currently several projects active and involved in biogas production and activities for training small businesses, farms and activities in the generation of bio-fuels.

Most of the industrial capacity projects involving biogas are currently from African palm farms reutilizing residual waters. However, certain swine

\footnotetext{
2 "WISIONS of sustainability" is an initiative of the Wuppertal Institute and supported by the Swiss-based foundation pro evolution. The name WISIONS is a combination of the initials of the Wuppertal Institute (WI).
}

and poultry farms and agricultural schools have begun biogas production. Ecopalsa is a company located in El Castaño village, $16 \mathrm{~km}$ on the highway between Progreso and Tela in the Northern coast of Honduras. This company works as a subsidiary of PALCASA ${ }^{3}$, which has project of biogas renewable energy that generates $930 \mathrm{~kW} / \mathrm{h}$. The energy is obtained through the capture of methane gas originated from the residual waters and biomass resulting from the palm tree extracting plant [35]. AGROTOR is a company located in San Alejo, Atlantida in the Northern coast of Honduras, which captures biogas in residual waters of African palm, currently generating 30,646 CERs. Project started in June 2008, producing approximately $3,000,000 \mathrm{~m}^{3} /$ year for use in an electric biogas plant of $860 \mathrm{~kW}$ and generating approximately 28,000 CERs/year [36].

The National Electrical Energy Company (ENEE) has supported the installation of bio-digestors in swine farms, such as one located in El Pino village near La Ceiba on the North Atlantic coast, and also in poultry farms, such as Finca Avicola Di Palma has also established bio-digestor projects in order to utilize their organic waste for biogas production [37]. However, there are plenty of small bio-digestor projects in small farms and households all over the country.

Agricultural school John F. Kennedy has also been a beneficiary of the ENEE's efforts with an installed bio-digestor with 2 tons of organic matter capacity for biogas production [38]. Agriculture school Zamorano through its Zamorano Renewable Energy Center has focused in the development of biogas projects, one of which is the training of small businesses through USAID ProParque Project, which is an economic growth and natural resources project that seeks to realign Honduras' economic and social development trajectory, as well as other types of training to rural technicians through the biogas for

\footnotetext{
${ }^{3}$ PALCASA is a company dedicated to the extraction of palm tree oil.
} 
energy project.

In terms of law and public policies in Honduras, biogas production is cited in the law for the Production and Consumption of Biofuels [39]. Ministry of Agriculture and Livestock is in charge of applying said law in terms of raw material production derived from agriculture or livestock for biofuel consumption. Said law defines as a priority of the use and import of raw materials for the production of biofuels and stipulates a new price for electricity generated from forest biomass. The law stipulates in its article 12, that the generation of electricity from biogas produced in the country has priority in the purchase processes required by the ENEE.

\subsubsection{Nicaragua}

Nicaragua has plenty small scale biogas projects, usually on small farms and rural households with livestock and swine organic matter. Projects, such as the Productive Food Program through Public Sector Agricultural Institutions (SPAR), have benefited 139 farmer families with the installation of bio-digesters with a one burner stove [40]. The Millennium Challenge Account of Nicaragua is seeking to reduce contamination and deforestation through the generation of energy using organic plant and animal waste with 160 bio-digesters for small and medium producers.

As a way to reduce firewood consumption, Nicaragua has established bio-digester projects through the Enxeñaria Sen Fronteiras Projet (Engineers without Borders), which involved three communities-La Concordia, San Sebastian de Yali and San Rafael del Norte through the installation of bio-digesters that would utilize organic matter produced on the farms in order to supply the kitchens with fuel [41]. Also the Dutch Project for Development is implementing the program for development of the biogas market in Nicaragua, with estimated 6 million dollar fund with the objective o finstalling bio-digesters in 6,000 small scale farms of the Boaco, Chontales, Leon, Matagalpa, Nueva Guinea and Rio San Juan areas, where bovine livestock is raised [42].

On an industrial scale, Nicaragua currently has the San Martin industries project that has planned the construction of $5,000 \mathrm{~m}^{3}$ capacity generator, which will power $100 \%$ of the energy needed in the slaughter house by utilizing the residue from the animals [43]. Also the Monte Rosa and San Antonio sugar plants are also utilizing the residual water from the sugar cane processing, which is used in the bio-digesters for energy production.

Regarding legislation and public policies, the Ministry of Mines and Energy has competency in the application and promotion of laws, and promotes the production of energy with alternative sources as indicated by decree No. 13/2004 establishment of the National Energy Policy and Law No. 532 for the promotion of electric generation with renewable sources and the strategic plan for the energetic sector 2007-2017, specifically section 4.3.2-a that orients the use of animal residue for the production of biogas as a safe and sustainable option for access to energy and support for electric generation [44].

\subsubsection{South America}

\subsubsection{Brazil}

In the 1980s, the first Brazilian laws considered the environment and its preservation of a comprehensive and integrated manner. But only from the 2000s, this concern reached other cross sectors, such as energy, when it was included, for example, the principles and objectives of the national policy for the segment:

(1) To increase in economic, social and environmental bases, the share of biofuels in the national energy matrix (writing amended by Law No. 11,097/2005);

(2) To encourage the generation of electricity from biomass and by-products of biofuel production, because of their character clean, renewable and complementary to hydropower (included by Law No. 12,490/2011).

Brazil's energy policy is also quietly encouraging and supporting the development of renewable energy 
sources, such as hydro, wind, solar and biomass. The study of the International Agency for Renewable Energies, called Renewable Power Generation Costs in 2014, points out that the cost-effectiveness of renewable energy generation technologies has reached historic levels. Sources like biomass can now provide competitive electricity compared to power generation arising from fossil fuels. The study also states that the electricity arising from geothermal, hydro and biomass offers lower cost than any other source [45]. The same study shows that Brazil is in the 2nd place in the ranking of countries with the highest cumulative installed renewable capacity for power generation through biomass with $11.5 \%$, behind the United States (12.7\%).

Regarding the installed potential of biogas plants in Brazil, there are currently 504 installed projects with a total capacity of 12,341,192 kW. Most of the projects presented as main source of generation sugarcane bagasse. Despite this little representation currently, the state has great potential for biogas generation, by having a representative industry and agribusiness [46].

In 2010, biogas began to be used in power generation, being considered an energy asset not an environmental liability. This energy source has become subject of debate and important international agendas. Among the most important regulations, seeking to give security to investors and producers of biogas can be highlighted:

(1) Normative Resolution (NR) 482/2012 from National Electric Energy Agency (ANEEL), which establishes the general conditions for the micro and mini generation access to distributed electricity distribution systems and the power compensation system, known internationally as net metering. In addition, the NR aims to reduce the barriers for small distributed generation installation, connected in voltage distribution;

(2) Technical note 13/2014 of the Energy Research Company (EPE), which was published in August 2014, with the energy demand research series 2050, and introduced biogas and biomethane in the scenario of the National Energy Planning. This study considers the current energy demand is limited due to loss of investment capacity of large generating projects, which increases the prospect of greater involvement of decentralized energy;

(3) In January 2015, the National Petroleum, Natural Gas and Biofuels Agency (ANP) published the resolution No. 8, regulating the use of biomethane in Brazil. Biogas is considered a raw fuel, while the biomethane is obtained by biogas purification and is considered a higher value fuel. According to this resolution, the biomethane produced from waste and livestock products (such as, pig manure and poultry), agricultural and agro-industrial happens to be treated in a manner similar to natural gas. This means that biomethane can have the same use of natural gas, including the same economic valuation, provided that it meets the quality requirements of the product set out in that resolution.

These regulations represented a major advance in the scenario of renewable energy in Brazil, positioning the biogas as an effectively important fuel in the Brazilian energy matrix.

One pilot project that is reference in Brazil is developed by Itaipu Binational-the world's largest hydroelectric power generation company, that has diversified its energy production from hydropower into other renewable sources, such as biogas. In 14 partnerships with Scania and International Centre for Renewable-Energy Biogas (CIBiogás-ER), they developed the project about rural and urban transitions with biogas and biomethane with animal wastes (Fig. 3). The animal wastes of a farm are transformed into biomethane to fuel of a bus Scania Euro 6, which was considered one of the most modern on public transport in the world. The property has 84,000 chickens and 750 cattle, which generates the average production of $1,000 \mathrm{~m}^{3} / \mathrm{d}$.

The biogas from the anaerobic treatment of waste biomass in digesters is a gaseous fuel with high energy 


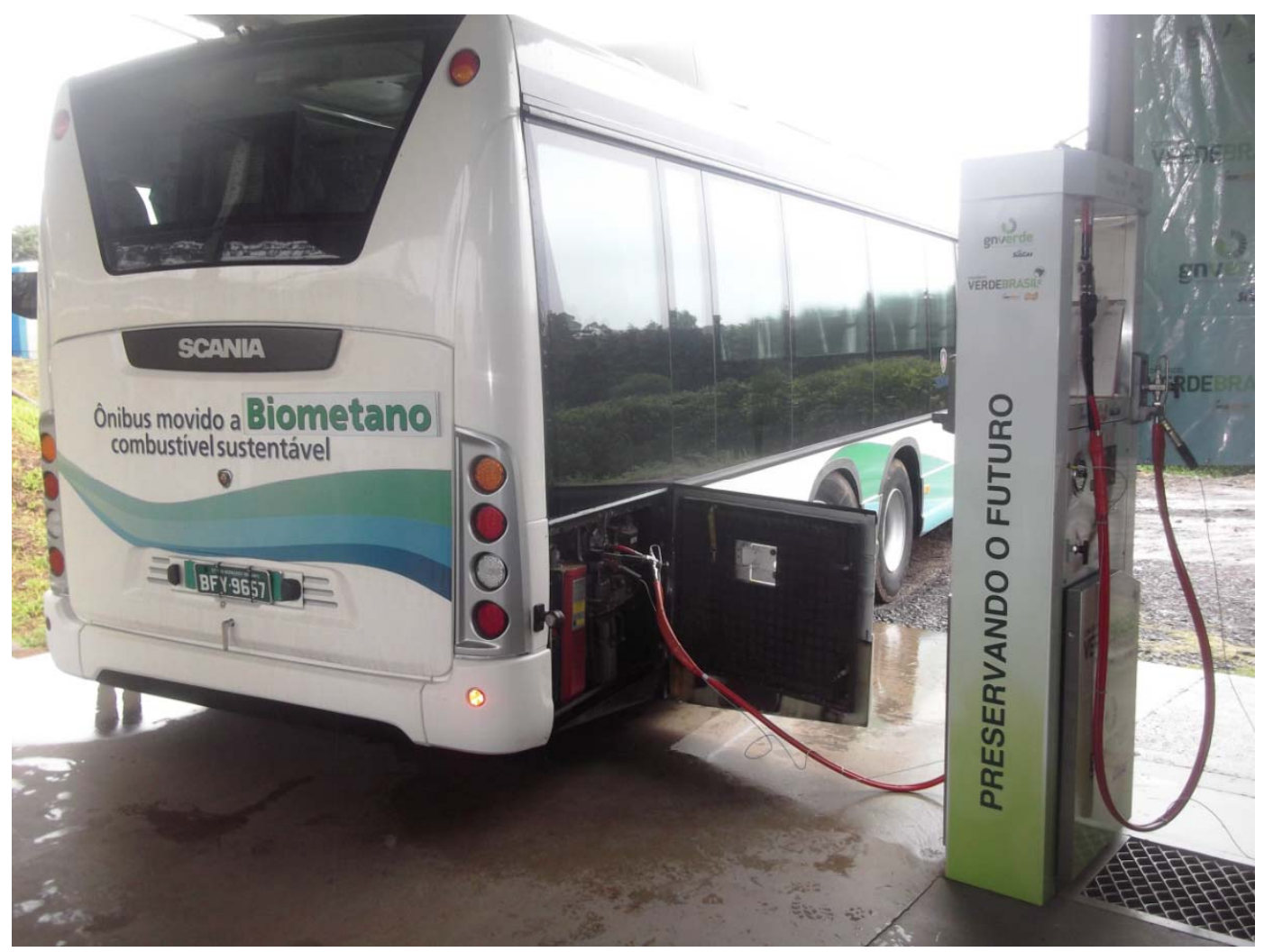

Fig. 3 Biomethane fueling station.

potential, however, is a raw material not a product. To get to the real and qualified biogas fuel potential, one must refine it in different intensities to obtain biomethane, which was considered a fuel product of potential to match the natural gas.

In $19 \mathrm{~d}$ of monitored tests, Scania Euro 6 carried 3,250 passengers in Itaipu complex, toured 3,000 km and consumed $74,558 \mathrm{~m}^{3}$ of biomethane. The average yield was $1.90 \mathrm{~km} / \mathrm{m}^{3}$, being equivalent to the consumption of compressed natural gas and $40 \%$ more efficient than the diesel. In addition, it avoids the emission of 100 tons of $\mathrm{CO}_{2}$ equivalent, a reduction of $70 \%$ compared to a diesel-powered bus [47].

This project demonstrates that in addition to essential characteristics to be considered a vehicle fuel quality and steady availability, biomethane can complement national energy matrix, remove environmental liabilities from highly polluting water resources and air, and turn them in the energy asset for rural and urban mobility.

\subsubsection{Ecuador}

Ecuador has established regulatory frameworks in the field of renewable energy and biofuels, emphasizing the energetic transformation to achieve the change of the productive matrix. The primary strategy within the national plan of good living states is: goal 4-to guarantee the rights of nature and promote a healthy and sustainable environment and policy 4.3-to diversify the national energy matrix, providing efficiency and greater share of renewable energies [48].

The Constitution of the Republic of Ecuador provides in article 413 that: "the state shall promote energy efficiency, development and use of practices and environmentally clean and safe technologies, as well as diversified, low impact renewable energy, and put in risk the food sovereignty, ecological balance of ecosystems and the right to water".

In 2008, Chile elaborated a document entitled "Ecuador Energy Policy 2008-2020”, in order to 
induce the model of environmentally friendly energy technologies, including biogas.

It may be noted that Ecuador is part of a system with emphasis energy to establish energy public policy in an environment of responsibility and sustainability.

Energetic sector in Ecuador has established two projects: the first, bioethanol for the automotive sector, which deals with biofuel investing 940 million dollars, and the second, biomass for the industrial Ecuadorian sector with an amount investment of 215 million dollars [49].

The Ecuadorian state has delegated to the private initiative projects of generation of electric power using non-conventional renewable energy for construction, installation and operation through the subscription of title qualifying (projects bigger than 1 MW) or enrollment in the registry under $1 \mathrm{MW}$ generators.

Currently, there are two biogas projects: the first is the project power generation with biogas produced at the landfill "Inga" I and "Inga” II of the Metropolitan district of Quito, with a capacity of 5.0 MW, and the second concerns the study of final environmental impact of power generation project using solid waste from Chone City with a capacity of $10.7 \mathrm{MW}$ [50].

\subsubsection{Chile}

In recent years, the government of Chile has consolidated a policy, aiming at achieving the objectives of safety, efficiency, environmental sustainability and equity of its energy supply energy policy. The strategy adopted has to identify and remove barriers that contribute to poor development of investments in these technologies and an unfair competition between non-conventional renewable energy and traditional forms of energy supply.

Due to its characteristics, most biogas projects have less than 9 MW electrical power. Furthermore, in the case of projects associated with agricultural waste, for cost reasons, probably its most viable option is connection to the distribution network. According to current regulations, projects of this type, which is not more than $9 \mathrm{MW}$ interconnected power distribution facilities, are referred to as small distributed generation means (SDGM). The general electricity service law establishes the obligation of distribution companies allowed to connection to its facilities by SDGM. For its part, the supreme decree No. 244 of 2005 from the Ministry of Economy, Development and Reconstruction, establishes procedures for the integration of these projects to the distribution systems, as well as the rights and obligations to be observed in the relationship between distributors and owners of SDGM [31].

According to current regulations, any generating unit shall communicate in writing to the system interconnection, with a minimum of six months, both the National Energy Comission and the corresponding center for economic load dispatch.

Additionally, generation works can not enter service until you contact $15 \mathrm{~d}$ prior to the Electricity and Fuels Department (SEC). This communication shall indicate at least a general description of the works to be placed in service, a list of the main equipment and materials, technical characteristics and indication of whether they are new or reconditioned. Design requirements and information to deliver by the generators are described in detail in numerical taxonomy and multivariate system (NTSYSpc), which are valid for any form of generation that integrates an electrical system.

According to the Centre for Renewable Energies [51], there are about 43 MW of installed electric capacity of biogas in Chile, which are supplied to the CIS. However, it is estimated that the gross potential of this source for both thermal and/or electrical projects is around 1,400 MW. Additionally, a total of 2.9 MW are under construction, which is intended to inject the SIC. The main biogas projects operational nation wide are:

(a) Los Angeles Agricultural Biogas Plant, located in the city of Los Angeles, in South-Central Chile 
(Fig. 4). This plant began operating in late 2011 and its current installed capacity was $2.2 \mathrm{MW}$, which aims to be expanded to $4 \mathrm{MW}$, mainly using the manure of 3,000 cattle and agricultural waste. Connected to the CIS through the General Electric Company (GEC), its heat is used to fuel a greenhouse tomato of 2 ha, which generates five times higher performance than the traditional system;

(b) Biogas Plant Tamm, located in the Fundo Rinconada, O'Higgins (South Chile). It generates biogas from a dairy waste site. Its processing capacity is $75 \mathrm{~m}^{3} / \mathrm{d}$ of cattle slurry, allowing a generation of 80 $\mathrm{m}^{3} / \mathrm{h}$, equivalent to $190 \mathrm{~kW}$ of installed power. Its operational cost is US \$30/MWh.

\subsection{Comparison of Public Policy Implications of the Biogas Scenario}

According to Scott and Pasqualetti [52], "policy initiatives that view energy and water in joint management terms and more fully unlock the potential of conservation, efficiency and renewable energy sources are required. This is not simply a question of planning for optimal resource use”. The authors affirm that "collaborative policy-making, which involves public decision-makers, private initiative and a range of stakeholders, will be needed to counter special-interest groups' influence over infrastructure

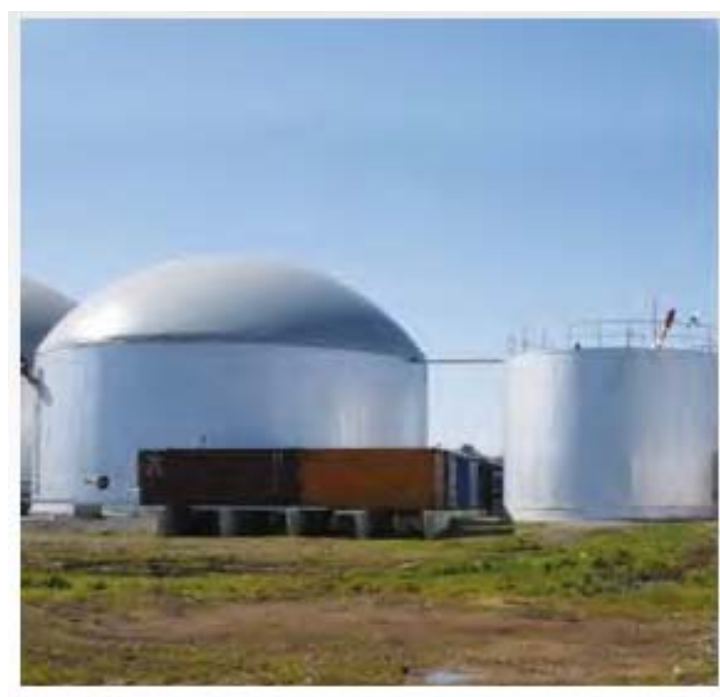

Fig. 4 Biogas plant in Chile.

Source: HBS Energía S.A. Company, 2014. development and energy and water policy”.

In this sense, policies that can be implemented to alleviate energy insecurity are: (1) to manage risks to avoid disruptions in the supply; (2) to overcome the lack of generation capacity; (3) to facilitate access to renewable sources; (4) to change the energy matrix and its dependence on imported energy [52].

Analyzing the public policies regarding biogas of the six countries, it is possible to affirm that all of them had some advances in the recent years. Mexico created the law for the use of renewable and energy transition financing in 2008 and other regulations about biogas uses, beside biogas programme, the project removing barriers to GHG mitigation in medium scale livestock agricultural activities and Biobolsa system.

Honduras implemented the law for the production and consumption of biofuel in 2007, that is stimulating farms to produce biogas. Nicaragua established the National Energy Policy in 2004 and the Law No. 532 for the promotion of electric generation with renewable sources.

Brazil is one of the countries with more biogas regulation, such as, the Brazilian Electricity Regulatory Agency (ANEEL) normative resolution 482/2012 and technical note 13/2014, which introduced biogas and biomethane in the scenario of the National

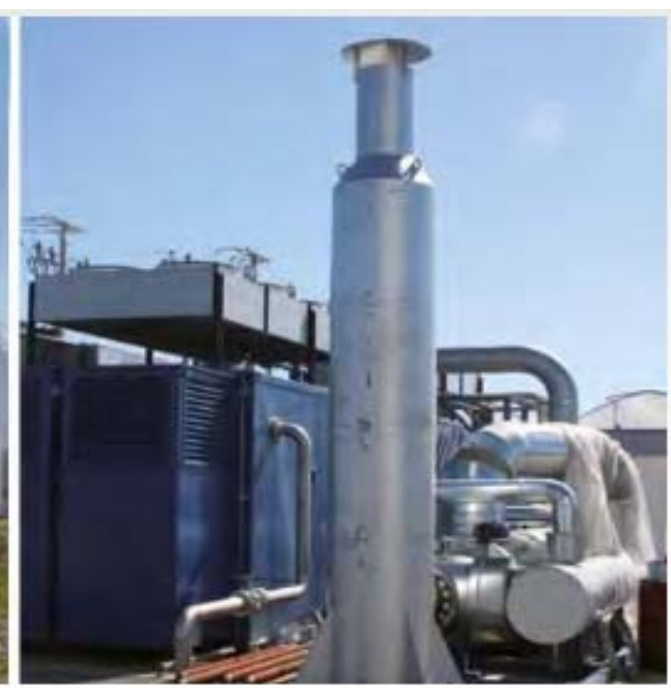


Energy Planning, besides the resolution No. 8 of ANP regulating the use of biomethane in the country. In 2008, Ecuador created the "Ecuador Energy Policy 2008-2020”, encouraging environmentally friendly energy technologies, including biogas.

In recent years, Chile has consolidated some polices to achieve the objectives of safety efficiency, environmental sustainability and equity of its energy supply energy policy. The general electricity service law established the obligation of distribution companies who were allowed to connection to its facilities, such as, the energy generated by biogas.

\section{Conclusions}

Water, energy and food are essential to the social and economic development of a country, and their improvement implies the continued growth of economic activity. As a result, there are growing and populous cities with a consequent rise in demand for these three sources. In this constant cycle, the world determinedly searches for renewable energy from sustainable sources, which even should be the basis of a new energy model.

Considering that biogas is a renewable source of energy available in all countries, it provides multiple economic, environmental and social benefits, which include: (1) electrical and thermal energy; (2) liquid and solid high-quality organic fertilizer for soil improvement; (3) reduction of odor; (4) any possibility of contamination of ground and surface waters; (5) ability to earn income from the sale of bio-sludge as a fertilizer; (6) reduction of emissions of greenhouse gases; (7) revenue from the possible reuse of solid digested as beds for cattle.

In the paper, it was concluded that the six countries studied has an important biogas production. Despite Honduras and Nicaragua having the lowest biogas potential (908 GW and 1,192 GW, respectively), they are countries where this energy would have a meaningful social effect, due to the low access to electricity (82.2\% and 77.9\%). Mexico has an elevated
$\mathrm{CO}_{2}$ emission, which could be reduced by the great potential for biogas production (13,362 GW). Brazil also has an expressive biogas production potential $(70,830 \mathrm{GW})$ and lower production of $\mathrm{CO}_{2}$.

There are actions and public policies being implemented in all of the countries to diminish the use of fossil fuels and promote biogas energies. Laws and regulations are promoting the implementation of biogas plants in these Latin American countries.

Through comparative scenarios and analysis of public policy perspectives, a trend towards the development and use of biogas can be identified. In most of these countries, policy makers are promoting the process of energy generation through the establishment of laws and policies favoring the renewable energy generation. The private sector is following the same path and becoming aware of the importance of renewable energy sources versus petroleum based energy, and depending on its potential, most of them have begun the switch.

Subsequently, the transformation of the country's energy matrix requires not only the adoption of new instruments and specific policies, such as the recent price regulation favorable to electricity from renewable energy and incentives formulated to encourage the production of biofuels, but also a change in planning and structures that have shaped a matrix centered on fossil fuels [53].

The expansion of renewable energy, such as biogas, provides a wider range of waste materials that may be recovered in digester system, providing best solution for both food and energy. Furthermore, it can assist in reducing the dependence on foreign energy sources, the susceptibility of international oil prices and the long-term environmental impacts of carbon emissions.

\section{Acknowledgments}

The authors thank Coordination for the Improvement of Higher Education Personnel (CAPES) for the financial support, Pontifical Catholic 
University of Paraná (PUCPR) for the technical support, and International Center of Renewable Energies/Biogas and International Center of Hydroinformatics for the data availability.

\section{References}

[1] United Nations Department of Economic and Social Affairs. 2014. "World Urbanization Prospects.” Accessed July 06, 2015. http://esa.un.org/unpd/wup/.

[2] Organização de Cooperação e Desenvolvimento Económico (OECD). 2011. "Towards Green Growth.” Accessed July 06, 2015. http://www.oecd.org/greengrowth /48536946.pdf.

[3] Food and Agriculture Organization of the United Nations (FAO). 2009. "2050: A Third More Mouths to Feed.” Accessed June 10, 2015. http://www.fao.org/news/story/ en/item/35571/icode/.

[4] United Nations (UN). 2014. "World Urbanization Prospects, 2014.” Accessed June 10, 2015. http://esa.un.org /unpd/wup/Highlights/WUP2014-Highlights.pdf.

[5] United Nations (UN). 2012. "The Future We Want." Accessed August 12, 2015. http://www.un.org/disabilities/ documents/rio20_outcome_document_complete.pdf.

[6] Leimgruber, W. 2015. "The Food We Waste-Material and Ethical Issues in Geography.” Journal of Agricultural Science and Technology B 5 (1): 1-14.

[7] Fuchs, C., Bogatov, V., and Eimannsberger, J. 2011. "Competitiveness and Risk of Crop Production, Milk Production and Biogas Production with Respect to Regional Resources.” Journal of Agricultural Science and Technology A 1 (7): 939-49.

[8] Domínguez, S. 2011. "Mexican Energy Matrix.” Accessed June 17, 2015. http://www.globalenergy. com.mx/index.php/k2/columnas/item/931-es-el-momento -de-mexico/931-es-el-momento-de-mexico. (in Spanish)

[9] Mexico National Institute of Statistics and Geography (INEGI). 2011. "Statistical Yearbook by State 2011." Accessed July 17, 2015. http://www.inegi.org.mx/ prod_serv/contenidos/espanol/bvinegi/productos/integraci on/pais/aepef/2011/Aepef2011.pdf. (in Spanish)

[10] International Renewable Resources Institute (IRRI) of México. 2014. Handbook for the Implementation of Agricultural Livestock Methane Capture Projects in Mexico. México: IRRI.

[11] OLADE. 2014. "Improving Access to Energy Markets in Honduras.” Accessed August 18, 2015. http://www.olade.org /wpcontent/uploads/2015/08/INFORME-FINALTALLE R-WF-HONDURAS.pdf. (in Spanish)

[12] Economic Commission for Latin America and Caribe (ECLAC). 2009. "Central American Isthmus: Hydrocarbon Statistics.” Accessed August 18, 2015.
http://www.cepal.org/cgibin/getProd.asp?xml=/publicacio nes/xml/4/37684/P37684.xml\&xsl=/mexico/tpl/p9f.xsl\&b ase $=/$ mexico/tpl/top-bottom.xsl. (in Spanish)

[13] Flores, W. C. 2012. Energetic Sector of Honduras: Diagnosis and Energy Policy. Information System and Registry Investigators of Honduras. (in Spanish)

[14] United Nations Development Programme (UNDP). 2011. "Study of the Biogas Potential Development Initiatives at a Production Level in Honduras.” Accessed August 20, 2015. http://www.hn.undp.org/content/honduras/es/home /library/environment_energy/estudio-biogas.html. (in Spanish)

[15] Honduras National Power Company. 2015. "Power Generation.” Accessed August 24, 2015. http://www.enee.hn /index.php/electrificacion-nacional/generacion. (in Spanish)

[16] Nicaraguan Energy Institute. 2012. "Installed Capacity in Nicaragua.” Accessed August 20, 2015. http://www. elnuevodiario.com.ni/infografia/407. (in Spanish)

[17] Ministry of Energy and Mines (MEM). 2012. "Ministry of Energy and Mines Exposes Changing in the Energy Matrix in Congress Rio 2012.” Accessed August 23, 2015. http://www.mem.gob.ni/index.php?s=1\&idp=174 \&idt=2\&id=444. (in Spanish)

[18] World Bank. 2015. " $\mathrm{CO}_{2}$ Emissions (Metric Tons per Capita).” Accessed September 21, 2015. http://data.worldbank.org/indicator/EN.ATM.CO2E.PC.

[19] Central America Product Center. 2015. "Nicaragua.” Accessed August 23, $2015 . \quad$ http://www. centralamericaproduct.org/sp/introduction.php?c=n119.

[20] Nicaraguan Institute of Statistical Studies. 2011. "Zero Hunger: Progress and Challenges.” Accessed September 23, 2015. http://www.ieepp.org/wp-content/plugins/ download-monitor/download.php?id=148. (in Spanish)

[21] Coordinator Ministry of the Strategic Sectors. 2013. “National Energy Balance 2013.” Accessed July 13, 2015. http://www.sectoresestrategicos.gob.ec/wp-content/uploa ds/downloads/2014/02/Balance-Energético-Nacional-201 3-base-2012.pdf. (in Portuguese)

[22] Ministry of Mines and Energy of Brazil. 2014. "Brazilian Energy Review.” Accessed August 27, 2015. http://www.mme.gov.br/documents/1138787/1732840/Re senha+Energética+-+Brasil+2015.pdf/4e6b9a34-6b2e-48f a-9ef8-dc7008470bf2.

[23] Energy Research Company (EPE). 2014. "National Energy Report 2014.” Accessed August 29, 2015. http://www.epe.gov.br/Estudos/Documents/BEN\%20201 4\%20Rel\%20S\%C3\%ADntese\%20ab\%202013a.pdf.

[24] Itaipu Binational. 2013. "Biogas Potential in Brazil." Accessed August 23, 2015. https://www.itaipu.gov.br/ sala-deimprensa/noticia/versao-ampliada-de-"biogasener gia-invisivel”-e-lancada-no-show-rural.

[25] Coordinator Ministry of Strategic Sectors in Ecuador. 

American Countries Regarding Biogas from Agriculture and Livestock

2013. “Ecuador’s Energy Matrix.” Accessed August 30, 2015. http://www.sectoresestrategicos.gob.ec/wpcontent/ uploads/downloads/2014/03/Web-Sectores-Estratégicos-p ara-el-Buen-Vivir-01.pdf.

[26] Peláez-Samaniego, M. R., Garcia-Perez, M., Cortez, L. A. B., Oscullo, J., and Olmedo, G. 2007. "Energy Sector in Ecuador: Current Status.” Energy Policy 35 (8): 4177-89.

[27] Ecuador's National Institute of Statistics and Census. 2013. "Economics Statistics.” Accessed July 30, 2015. http://www.ecuadorencifras.gob.ec/censo-nacionalecono mico/.

[28] Cornejo, C., and Wilkie, A. C. 2010. "Greenhouse Gas Emissions and Biogas Potential from Livestock in Ecuador.” Energy for Sustainable Development 14 (4): 256-66.

[29] World Bank. 2014. "Indicators.” Accessed August 27, 2015. http://data.worldbank.org/indicator.

[30] Ministry of Energy of Chile. 2014. "Chilean Energy Matrix.” Accessed August 29, 2015. http://www. minenergia.cl/estrategia-nacional-deenergia-2012.html.

[31] Ministry of Energy of Chile. 2012. "Planning Guide for Biogas Projects in Chile.” Accessed July 26, 2015. http://www.aproval.cl/manejador/resources/guiaplanifica cionproyectosbiogasweb.pdf.

[32] Universidad de Chile. 2013. "About Chile: Territorial Presentation.” Accessed July 26, 2015. http://www.uchile.cl/portal/presentacion/la-u-ychile/acerc a-de-chile/8035/presentacion-territorial. (in Spanish)

[33] Kunz, A., and Oliveira, P. 2006. "Animal Waste for Biogas Generation.” Agricultural Policy Journal 15 (3): 28-35.

[34] Ministry of Energy of Mexico. 2009. "Renewable Energy for Sustainable Development in Mexico.” Accessed August 30, 2015. http://www.energia.gob.mx/res/0/ ER_para_Desarrollo_Sustentable_Mx_2009.pdf.

[35] Alvarenga, F. 2013. "Inaugurated Biogas Plants and Refiner.” Accessed July 20, 2015. http://www.laprensa.hn/economia/344804-97/inauguranplantas-de-biogás-y-refinadora. (in Spanish)

[36] BIOTEC. 2009. “Boletin BEB.” Accessed July, 20, 2015. http://biotec.net/archivos/Boletines/Externos/PV1-C92\%2 0(Boletin\%20Externo\%20Biotec\%20BEB)\%20Septiemb re-2009.pdf.

[37] Matamoros, D. 2012. "Systematization of Biodigestion Project: DiPalma Farm, S.A. de C.V.” IHCIT, Tegucigalpa. Accessed August 14, 2015. https://acchonduras.files.wordpress.com/2014/07/proyect o-de-biodigestion-finca-avc3adcola-dipalma.pdf.

[38] Proceso Digital. 2011. "ENEE Installs Biodigesters in Atlantida.” Accessed July 27, 2015. http://www.proceso.hn /component/k2/item/47591.html. (in Spanish)

[39] Honduras. 2007. "Law for the Production and
Consumption of Biofuels.” Accessed September 18, 2015. http://www.poderjudicial.gob.hn/juris/Leyes/Ley\%20para \%20la\%20Produccion\%20y\%20Consumo\%20de\%20Bio combustibles.pdf.

[40] Nicaraguan Basic Food Company (ENABAS). 2007. "Biodigestores Delivered to 139 Peasant Families." Accessed July 12, 2015. http://www.enabas.gob.ni/noticias/21. (in Spanish)

[41] Prado, A. 2011. "Design and Implementation of Biodigestores in Rural Communities from Parte Alta de la Subcuenca del Rio Viejo, Nicaragua.” Accessed July 12, 2015. http://galicia.isf.es/files/pfc/pfc_agustin_ prado.pdf. (in Spanish)

[42] Perez, W. 2014. "Nicaragua Commitment to Biogas for Energy in Rural Areas, La Prensa, 2014.” Accessed July 14, 2015. http://www.laprensa.com.ni/2014/05/04/ nacionales/193122-nicaragua-apuesta-por-el-biogas-parae nergia-en-zonas-rurales. (in Spanish)

[43] Green Projects. 2014. "Green Project Launches the First Biogas Project in Nicaragua.” Accessed July 14, 2015. http://greenprojects.com.ni/?p=81. (in Spanish)

[44] Multilateral Investment Fund/Inter-American Development Bank. 2010. Evaluating Study of Biogas Potential of IDB/MIF Projects and the Implementation Strategy for a Biogas Program in Nicaragua.

[45] The International Renewable Energy Agency (IRENA). 2015. "Renewable Power Generation Costs in 2014: An Overview.” Accessed August 30, 2015. http://www.irena.org/DocumentDownloads/Publications/I RENA_RE_Power_Costs_2014_report.pdf.

[46] Brazilian National Electric Energy Agency (ANEEL). 2015. "Biomass Plants in Operation in 2015.” Accessed August 30, 2015. http://www.aneel.gov.br/aplicacoes/ capacidadebrasil/OperacaoGeracaoTipo.asp?tipo=5\&ger= Combustivel\&principal=Biomassa.

[47] International Center of Renewable Energies/Biogás. 2015. “Biomethane Project.” Accessed August 30, 2015. https://cibiogas.org/scania_master_euro6.

[48] Ecuador's National Planning and Development Secretariat. 2010. "National Plan for Good Living 2009-2013: Building a Pluri National and Intercultural State.” Accessed August 13, 2015. http://www.unosd.org/content/documents/96National\%20 Plan\%20for\%20Good\%20Living\%20Ecuador.pdf.

[49] Ecuador's Coordinator Ministry of Energy Sectors. 2014. "Investment Catalog of Strategic Sectors 2015-2017." Accessed August 2015. http://www.sectoresestrategicos.gob.ec/wpcontent/upload s/downloads/2015/04/Primera-parte-Catálogo-de-Inversio nes-de-los-Sectores-Estratégicos-2015-2017.pdf

[50] Ecuador's National Electricity Council (CONELEC). 2012. "Environmental Impact Study: Power Generation 

American Countries Regarding Biogas from Agriculture and Livestock

Project of Cantón Chone-10.7 MW.” Accessed August 09, 2015. http://www.conelec.gob.ec/images/documentos/ doc_10182_EIAD\%20Chone\%20nov\%2012.pdf.

[51] Centre for Renewable Energies. 2014. "State of Renewable Energies Projects in Chile.” Accessed August 09, 2015. http://www.cifes.gob.cl/mailing/2014/agosto/ REPORTEAgosto2014.pdf. (in Spanish)

[52] Scott, C. A., and Pasqualetti, M. J. 2010. “Energy and
Water Resources Scarcity: Critical Infrastructure for Growth and Economic Development in Arizona and Sonora.” Natural Resources Journal 50 (3): 645-82.

[53] Ecuatoriano Center for Environmental Law (CEDA). 2012. "Towards a Diversified Energy Matrix in Ecuador." Accessed August 09, 2015. http://www.ceda.org.ec/ descargas/publicaciones/matriz_energetica_ecuador.pdf. (in Spanish) 